\title{
The Effect of Socratics Questioning Method in Improving Students' Speaking Skill and Critical Thinking in English as a Foreign Language Learning
}

\author{
Woro Kusmaryani ${ }^{1, *}$ \\ ${ }^{1}$ English Education Department, Universitas Borneo Tarakan, Indonesia \\ *Corresponding author. Email: worokusmaryani@borneo.ac.id
}

\begin{abstract}
The purpose of this paper is to look at how the Socratic questioning method can be used in EFL teaching and learning. This paper not only describes the method's beliefs and practices, but also assesses its efficacy in improving speaking ability and critical thinking. As the research design, convergent parallel mixed methods provides complete data (test, observation, and interview) to provide a clear interpretation of the Socratic questioning approach. This study was conducted with one teacher and 38 English department students at Tarakan State University in Indonesia. To evaluate quantitative data, Wilcoxon statistical analysis and Rank Spearman correlation analysis were utilized (pre-test and posttest). To evaluate qualitative data, this study used description as analysis, inductive analysis, constructionist analysis, and coding (observation and interview). The Socratic questioning approach has three stages in its execution (preparation, running process, and assessment). The method's investigation reveals that it is beneficial in improving students' speaking skills and critical thinking (significance value.000 0.05). The Rank Spearman correlation demonstrates a strong link between speaking ability and critical thinking (coefficient .866). By selecting and altering topic discussion and Socratic questions, this technique is ideal for teaching and learning EFL. Through the analysis of Socratic questions that stimulate speaking skill and critical thinking, this study establishes the adoption and adaption of the Socratic questioning approach in EFL teaching and learning in Indonesia.
\end{abstract}

\section{Keywords: Speaking Skill, Socratic Questioning Method, Critical Thinking}

\section{INTRODUCTION}

The Teaching English as a Foreign Language (EFL) speaking skills in Indonesia is difficult. When it comes to enhancing their students' oral skills, EFL teachers confront various obstacles and hurdles. According to Fauzan (2016) [1] and Sayuri (2016) [2], students' ability to communicate is influenced by their mastery of vocabulary, pronunciation, grammar, and comprehension as language aspects. Students' success in speaking is influenced by psychological elements such as selfconfidence, fear of making a mistake, and low motivation [3].

Irmawati (2016) [4] also looks into the environmental factors that cause kids to have difficulty increasing their verbal skills. For starters, pupils have a large number of tasks from previous classes. Second, the availability of speaking media is limited. Third, pupils' outside-of-class exercise is inadequate. Fourth, the teacher's ability to innovate in the classroom when it comes to teaching speaking is limited. Fifth, speaking materials are unsuitable. Sixth, the needs of pupils are not synchronized: Finally, a teacher's ability to talk has an impact on pupils' performance. Finally, students' motivation to talk is influenced by their opportunities to speak and feedback.

Critical thinking, in addition to speaking ability, is a key talent that students must develop. Critical thinking is incorporated into Indonesian curriculum to help students strengthen their reasoning skills and be able to critically examine texts. It is the role of the instructor to help students develop critical thinking skills. Teachers incorporate critical thinking into the selection of teaching techniques and materials in language teaching and learning. The teacher's goal is to help pupils improve their critical thinking skills as well as their linguistic 
skills. According to Masduqi (2011) [5], the purpose of language learning and the integration of critical thinking is meaning-making. Transformative learning techniques such as explicit teaching, memory-based learning, rote learning, and focus group discussion, according to Djiwandono (2013) [6], can be applied in the classroom to promote critical thinking. Indah and Kusuma (2016) [7] point out that students' linguistic competency has an impact on their critical thinking abilities.

The Socratic method of questioning is the most effective way to teach critical thinking [8]. The core premise of this method is truth-seeking, in which the dialogue assists the teacher and students in evaluating knowledge assumptions through deep and continual questions [9], [10], [11], [12]. This strategy uses evidence and pertinent data to construct logical arguments that can change teacher-student attitudes on the subject [13]. Communication becomes a significant aspect of the learning process when the teacher's and students' engagement influences the learning process [14]. Active involvement, thinking elements, thinking standards, and thinking system are the core focus of this instructional style in increasing critical thinking, according to Elder and Paul (2007) [15].

Previous studies on the Socratic questioning style found that it helped people improve their critical thinking skills [16], [17], [18]. There is little study on the use of the Socratic questioning method in EFL teaching and learning. It piques scholars' curiosity in looking at this way of teaching EFL speaking ability. The researchers are interested in knowing more about how the Socratic questioning method is used in EFL teaching and learning. The researchers aim to see if this strategy may help students improve their speaking skills as well as their critical thinking skills. In this strategy, the researchers aim to determine if there is a link between critical thinking and speaking ability. The researchers also wish to look into how this method is perceived by teachers and students in EFL teaching and learning, particularly in the teaching of EFL speaking skills.

\section{METHODOLOGY}

The design of this study is convergent parallel mixed methods [19], which provides complete data (test, observation, and interview) in order to provide a clear interpretation of the Socratic questioning method. This study was conducted with one teacher and 38 English department students at Tarakan State University in Indonesia. The researchers used six types of Socratic questions to conduct pre- and post-tests on students' speaking ability and critical thinking in order to determine the effectiveness of the Socratic questioning method. The purpose of the observation was to verify and explain the Socratic questioning method's operation. The researchers conducted interviews with the teacher and students to learn about their perspectives on the use of the Socratic questioning method. To evaluate quantitative data (pre-test and post-test), Wilcoxon statistical analysis and Rank Spearman correlation analysis were utilized (Sheskin, 2007). To evaluate qualitative data, this study used description as analysis, inductive analysis, constructionist analysis, and coding (observation and interview).

\section{RESULT AND DISCUSSION}

This The researchers used the Socratic questioning method in sixteen meetings for this study. The researchers and the teacher introduced the approach and provided explicit instructions on how to execute the method in one semester during the first meeting. The researchers and teacher then conducted a pre-test on speaking ability and critical thinking to obtain preliminary results. From the second to the seventh meeting, the teacher and students used selected themes to implement the Socratic questioning method. The researchers and the teacher conducted a mid-test at the eighth meeting to determine how well the pupils had adapted to the strategy. The teacher and the students continued to implement the strategy from the ninth to the fifteenth meeting. The researchers and the teacher conducted a post-test at the last meeting to assess the students' progress following the implementation of the teaching technique.

\section{The Implementation of Socratic Questioning Method in Teaching EFL Speaking Skill \\ First Stage: Preparation}

The researchers began this stage by creating a website and a handbook to provide clear information and assistance about the Socratic questioning method. The researchers and the teacher then synchronized the background information of the teacher, the background information of the students, and the course objectives. Following that, the researchers and the teacher chose suitable themes and instructional materials. The researchers and the teacher then worked together to establish a syllabus and a learning contract. The researchers and the teacher then gave the pupils with appropriate website links and e-books. The researchers and the teacher then chose acceptable Socratic questions from the six categories available. The pupils were then introduced to the teaching program by the researchers and the teacher. Finally, the researchers and the teacher evaluated the pupils' ability to talk and think critically (pre-test). 


\section{Second Stage: Socratic Questioning Method Practice}

The researchers and the teacher started with the seating arrangement at this point (the outer circle and the inner circle). The researchers and the teacher then divided the pupils into two groups: the outer circle and the inner circle. The teacher then brought up a hot topic for debate. The inner circle students had the first opportunity to address the subject, while the outer circle students observed the inner circle conversation. The teacher then gave students in the outer circle the option to provide input on the inner circle's conversation before continuing the unfinished debate. The teacher and students wrapped off the topic by summarizing it. Finally, students reflected on their performance and the subject of the debate.

\section{Third stage: Evaluation}

The researchers and the teacher began this stage by selecting an appropriate topic for the students' assessment. Following that, the researcher and the teacher chose six different sorts of Socratic questions. Following that, the researchers and the teacher used a grading system to evaluate the students' speaking ability and critical thinking. The pupils were then graded using the scoring rubric. Finally, the teacher announced the students' grades.

\section{The Socratic Questions' Frequency}

The frequency with which Socratic questions were utilized during the conversation was documented by the researchers. Socratic questions are divided into six categories by Paul (2006). The first type of query is one that seeks clarity on a notion. Assumption questions fall into the second type. Questions on logic, reason, and evidence fall into the third group. The viewpoint and perspective questions fall within the fourth group. The implication and consequence questions fall within the fifth category. Questioning the question is the sixth category. The frequency of each type of Socratic inquiry is depicted in the graph below.

Chart 1. Socratic questions' frequency in one semester Socratic questions' frequency in one semester

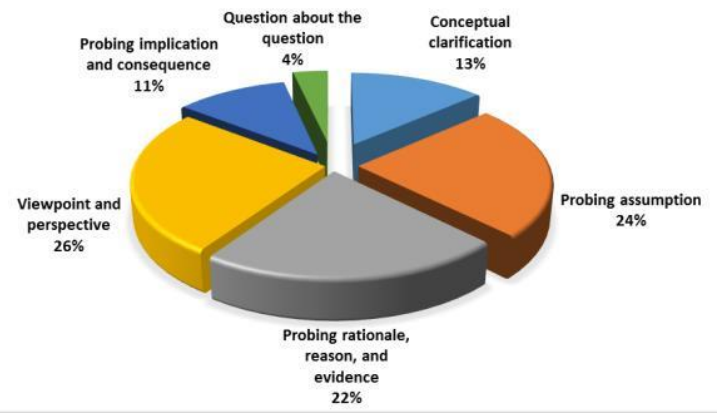

The students primarily asked questions about viewpoint and perspective, assumption and rationale, reason, and evidence, as seen in Chart 1. The conceptual clarification questions, as well as the implication and consequence questions, were not well-received by the pupils. The last category of Socratic questions was rarely asked by students (question about the question).

\section{Socratic Circle Speaking Pattern}

Each meeting began with the researchers and teacher arranging the kids' seats (the outer circle seats and the inner circle seats). After then, the teacher brought up a hot topic for debate. The inner circle students had the first opportunity to address the subject, while the outer circle students observed the inner circle conversation. The teacher then gave students in the outer circle the option to provide input on the inner circle's conversation before continuing the unfinished debate. The teacher and students wrapped off the topic by summarizing it. The following is an example of the Socratic circle's speaking pattern.

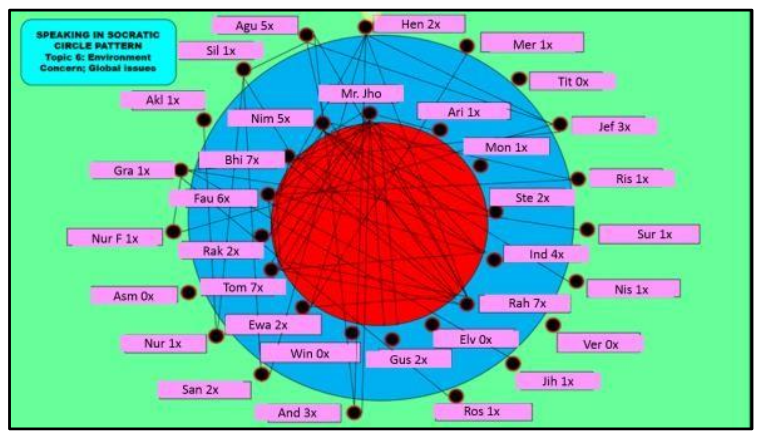

Figure 1. A sample of Socratic circle speaking pattern

The running process of the inner circle discussion and the outer circle conversation is depicted in the Socratic circle speaking pattern above. The lines in the diagram depict not just the interaction between the teacher and the pupils, but also the interaction between the students. The Socratic circle speaking pattern demonstrates a clear estimate of students' speaking frequency, allowing the teacher and students to perceive each other's contributions to the conversation. In the Socratic questioning method implementation, this pattern displays active and passive students.

The Effectiveness of the Socratic Questioning Method for the Students' Speaking Skill and Critical Thinking

\section{The result of speaking skill}

The researchers used Wilcoxon statistical analysis to determine the difference in students' speaking ability between pre-test and post-test data, confirming the efficiency of the Socratic questioning method in stimulating students' speaking ability. If Asymp. Sig is 
less than 0.05, Wilcoxon statistical analysis yields a favorable outcome. The students' pre-test topic was gadgets and social media, and their post-test theme was HIV, AIDS, and free sex. The researchers and teachers used the six kinds of Socratic inquiries to ask the students the questions. Students' fluency, word pronunciation, speaking accent, vocabularies, grammar in use, and speaking details are all covered by the speaking scoring rubric. The following tables show the difference in speaking skill between the pre-test and post-test results.

Table 1. The result of speaking skill

\begin{tabular}{|l|r|r|r|r|}
\hline \multicolumn{2}{|c|}{$\mathbf{N}$} & \multicolumn{1}{c|}{ Mean Rank } & \multicolumn{1}{c|}{ Sum of Ranks } \\
\hline & & $0^{\mathrm{a}}$ & .00 & .00 \\
\hline Negative Ranks & & $38^{\mathrm{b}}$ & 19.50 & 741.00 \\
Positive Ranks & & $0^{\mathrm{c}}$ & & \\
Ties & 38 & & \\
Total & & & \\
\hline a. Post-test $<$ Pre-test & & & \\
b. Post-test $>$ Pre-test & & & \\
c. Post-test $=$ Pre-test & & & \\
\hline
\end{tabular}

After comparing students' speaking pre-test with their speaking post-test, Wilcoxon statistical analysis on table 1 shows that all of the students had positive growth in speaking ability.

Table 2. Wilcoxon statistical analysis result of speaking skill

\begin{tabular}{|c|c|}
\hline \multicolumn{2}{|c|}{ Test Statistics ${ }^{b}$} \\
\hline & Post-test - Pre-test \\
\hline $\begin{array}{l}\mathrm{Z} \\
\text { Asymp. Sig. (2-tailed) }\end{array}$ & $\begin{array}{r}-5.391^{\mathrm{a}} \\
.000\end{array}$ \\
\hline $\begin{array}{l}\text { a. Based on negative ranks } \\
\text { b. Wilcoxon Signed Ranks Test }\end{array}$ & \\
\hline
\end{tabular}

Table 2 shows that after using the Socratic questioning method, all of the students' speech skills improved significantly (Asymp. Sig. is.000 0.05).

\section{The result of critical thinking}

The researchers used Wilcoxon statistical analysis to determine the difference in students' critical thinking between pre- and post-test data, confirming the usefulness of the Socratic questioning method in stimulating critical thinking. If Asymp. Sig is less than 0.05, Wilcoxon statistical analysis yields a favorable outcome. The students' pre-test topic was gadgets and social media, and their post-test theme was HIV, AIDS, and free sex. The researchers and teachers used the six kinds of Socratic inquiries to ask the students the questions. Students' accuracy in interpreting statements, images, questions, and facts are included in the scoring rubric for critical thinking, as well as their analysis, arguments, and views. It is founded on the ability to reason, ethical judgment, and the explanation of procedures and outcomes. The following tables demonstrate the critical thinking difference between pretest and post-test results.

Table 3. The result of critical thinking

\begin{tabular}{|c|c|c|c|}
\hline & \multirow[b]{2}{*}{$\mathrm{N}$} & \multicolumn{2}{|r|}{ Ranks } \\
\hline & & Mean Rank & Sum of Ranks \\
\hline Negative Ranks & $0^{\mathrm{a}}$ & .00 & .00 \\
\hline Positive Ranks & $26^{b}$ & 13.50 & 351.00 \\
\hline Ties & $12^{\mathrm{c}}$ & & \\
\hline Total & 38 & & \\
\hline \multicolumn{4}{|c|}{ a. Post-test $<$ Pre-test } \\
\hline \multicolumn{4}{|c|}{ b. Post-test $>$ Pre-test } \\
\hline \multicolumn{4}{|c|}{ c. Post-test $=$ Pre-test } \\
\hline
\end{tabular}

After comparing students' critical thinking pre-test with their critical thinking post-test, Wilcoxon statistical analysis on table 1 shows that 26 students showed positive growth in critical thinking. After comparing the pre-test and post-test, the statistical analysis above identifies 12 students that have the same degree of critical thinking.

Table 4. Wilcoxon statistical analysis of critical thinking.

\begin{tabular}{|l|r|}
\hline \multicolumn{2}{|c|}{ Test Statistics $^{\text {b }}$} \\
\hline \multicolumn{2}{|c|}{ Post-test - Pre-test } \\
\hline Asymp. Sig. (2-tailed) & $-4.521^{\text {a }}$ \\
\hline a. Based on negative ranks & .000 \\
b. Wilcoxon Signed Ranks Test & \\
\hline
\end{tabular}

According to the Wilcoxon statistical analysis on table 4 , about half of the students in the class improved their critical thinking considerably after using the Socratic questioning method (Asymp. Sig. is.000 0.05).

\section{The Correlation between Speaking Skill and Critical Thinking}

Through SPSS software, Rank Spearman statistical analysis correlates speaking ability and critical thinking. The association is shown in the table below.

Table 5. The correlation between speaking skill and critical thinking

\begin{tabular}{|c|c|c|c|c|}
\hline \multicolumn{5}{|c|}{ Correlations } \\
\hline & & & SPEAKING & $\begin{array}{l}\text { CRITICAL } \\
\text { THINKING }\end{array}$ \\
\hline \multirow[t]{6}{*}{$\begin{array}{l}\text { Spearman' } \\
\mathrm{s} \text { rho }\end{array}$} & SPEAKING & $\begin{array}{l}\text { Correlation } \\
\text { Coefficient }\end{array}$ & 1.000 & $.866^{* *}$ \\
\hline & & Sig. (2-tailed) & & .000 \\
\hline & & $\mathrm{N}$ & 38 & 38 \\
\hline & $\begin{array}{l}\text { CRITICAL } \\
\text { THINKING }\end{array}$ & $\begin{array}{l}\text { Correlation } \\
\text { Coefficient }\end{array}$ & $.866^{\circ *}$ & 1.000 \\
\hline & & Sig. (2-tailed) & .000 & \\
\hline & & $\mathrm{N}$ & 38 & 38 \\
\hline
\end{tabular}

According to the Rank Spearman statistical analysis, the correlation coefficient between speaking ability and critical thinking is. $866^{* *}$, indicating that there is a significant association between the two. At 0.01 the asterisk symbols $(* *)$ add to the significance. Since its 
value of.000 0.05 , the association is significant. The positive correlation coefficient indicates a direct link between speaking ability and critical thinking, implying that pupils who improve their oral ability will have stronger critical thinking.

\section{Teacher-students Perception to the Implementation of the Socratic Questioning Method in Teaching and Learning EFL Speaking Skill}

The teacher who initially used the Socratic questioning method confessed that it allowed each pupil the opportunity to share their opinions and perspectives. This strategy encourages pupils to enhance their speaking skills and gain confidence in their ability to express themselves. This strategy improves the environment in the classroom. This strategy is suitable for use in the teaching and development of EFL speaking skills. The teacher stated that the success of this strategy was influenced by the pupils' preparedness.

Students who were exposed to the Socratic questioning method for the first time reported they noticed improvements in their speaking ability and critical thinking. They were eager to go deeper into the topic by expressing their thoughts, challenging the argument, presenting proof, and questioning their teacher and peers. Students' vocabulary is expanded and their language skills in hearing, reading, and writing are activated with a topical syllabus. In the conversation, the kids felt they had the same opportunity to speak. The pupils were satisfied with the explicit teaching and transparent evaluation in the Socratic questioning style. Students evaluated their growth in speaking and critical thinking as a result of their reflective practice in this manner.

The researchers in this study primarily borrowed the notion of the Socratic questioning method from Paul (2006) and used the six categories of Socratic questions in EFL teaching and learning to develop critical thinking and speaking ability. The strategy was also implemented in this study using Copeland's (2005) [20] Socratic method, which has been shown to promote students' critical thinking. The researchers tweaked the types of Socratic questions and teaching materials to fit it into EFL teaching and learning, particularly in the teaching of EFL speaking skills.

The application of the Socratic questioning approach took place in three stages. The first stage focuses on the method's preparation. The success of this strategy in the classroom is influenced by the teacher's readiness and the students' readiness at this point. According to Copeland (2005), the teacher should know the students' previous knowledge, the suitable materials, and the appropriate questions to utilize when preparing the Socratic Method. The method's operating procedure is the focus of the second stage. The debate in the inner circle and the outer circle is influenced by the teacher's and students' distinct responsibilities at this level. Burbules (1993) [21] emphasizes that the method's running process should be responsive and interactive, with the teacher and students establishing a joint understanding of the subject and evaluating the assumptions through the inquiry process. The method's evaluation is the emphasis of the third step. The examinations at this stage require a suitable selection of Socratic question types as well as good scoring on speaking ability and critical thinking. The researchers used a direct speaking examination, as described by Araghi and Amineh (2014) [22], to assess speaking ability, in which the examiners could interact directly with the students. It also included a conversational cloze (analytic scoring) that focused on fluency, pronunciation, vocabulary, grammar, and details [23], [24], [25]. Paul (1993) [26] argues that while measuring critical thinking, the main focus is on the students' ability to reason.

The researchers believe that implementing the Socratic questioning method in EFL teaching and learning improves not just students' critical thinking but also their language skills (Listening, Speaking, Reading, and Writing). Students might research a lot of information offline and online to support their arguments in the conversation, where they speak up about their thoughts and dispute the opinions of other students. Written reflective practice, in which students evaluate their performance in the conversation and assess the content of the topic, could help students improve their writing skills. This finding is comparable to those of Mott (2015) [27] and Pokorna (2009) [28], who found that using the Socratic questioning method increased students' vocabulary, improved their grammar, and helped them meet their language goals.

The researchers discovered that in critical thinking, the teacher and students may examine the subject, analyze assumptions through reasoning, give adequate data and evidence, and form a decision. Paul, Elder, and Bartell (1997) [29] back up the findings of this study by claiming that critical thinking skills include the ability to process information systematically, uncover the issue's ramifications, truly appreciate reality, and employ logic arguments for the objection. Critical thinking, according to the researchers, should be integrated and developed into language curriculum so that students can attain not just linguistic goals but also improve the quality of their speech. It agrees with Kabilan (2000) [30], who claims that students can use the language target at the same time as they think creatively and critically about the subject in order to achieve the language learning goal. 


\section{CONCLUSION}

The Socratic questioning method can be used to educate and develop English as a second language speaking skills. The results of the research show that this strategy greatly improves students' speaking and critical thinking skills (Asymp. Sig. is.000 0.05). The running process of the Socratic questioning approach in the class was influenced by material selection, Socratic question selection, and students' preparation. The use of technological aids such as internet access, electronic books, teaching-learning programs, and relevant website links will improve the socratic questioning method's implementation. EFL teachers who want to use this method in the classroom should pay close attention to their students' vocabulary, make certain changes to their teaching materials, and choose the six types of Socratic questions carefully. Future researchers will be challenged to examine and investigate the Socratic questioning method due to limitations in research focus, research participants, data gathering, and data processing.

\section{AUTHORS' CONTRIBUTIONS}

Woro Kusmaryani contributed to data collection, data analysis, writing original draft, reviewed literature, and editing the final manuscript.

\section{ACKNOWLEDGMENTS}

This research was supported by the English education department, Universitas Borneo Tarakan. The researcher would like to thank the lecturers and all the students who participated in this research.

\section{REFERENCES}

[1] U. Fauzan, "Enhancing Speaking Ability of EFL Students through Debate and Peer Assessment," EFL J., vol. 1, no. 1, pp. 49-57, 2016, doi: http://dx.doi.org/10.21462/eflj.v1i1.8.

[2] Sayuri, "English Speaking Problems of EFL Learners of Mulawarman University," Indones. J. EFL Linguist., vol. 1, no. 1, pp. 47-61, 2016, doi: http://dx.doi.org/10.21462/ijefll.v1i1.4.

[3] Ariyanti, "Psychological Factors Affecting EFL Students' Speaking Performance," ASIAN TEFL, vol. 1, no. 1, pp. 77-88, 2016, doi: http://dx.doi.org/10.21462/asiantefl.v1i1.14.

[4] D. K. Irmawati, "What Makes High-Achiever Students Hard to Improve Their Speaking Skill?," J. English Educ. Soc., vol. 1, no. October, pp. 71-82, 2016, doi: 10.21070/jees.v1i2.442.
H. Masduqi, "Critical Thinking Skill and Meaning in English Language Teaching," TEFLIN J., vol. 22, no. 2, pp. 185-200, 2011.

[6] P. I. Djiwandono, "Critical Thinking Skills for Language Students," TEFLIN J., vol. 24, no. 1, pp. 32-47, 2013.

[7] R. N. Indah and A. W. Kusuma, "Factors Affecting The Development of Critical Thinking of Indonesian Learners of English Language," IOSR J. Humanit. Soc. Sci., vol. 21, no. 6, pp. 86-94, 2016, doi: 10.9790/08372106088694.

[8] R. W. Paul, Thinker's Guide to the Art of Socratic Questioning. Santa Rosa, CA: Foundation for Critical Thinking, 2006.

[9] P. E. Michaelides, "Socratic Ignorance: Lifelong Teaching and Philosophical Education," Int. J. Arts Sci., vol. 6, no. 1, pp. 247-262, 2013.

[10] C. Nash, "Founders ' Continuing Roles in Schools Supporting Self-Directed Learning," Springer - Interchang., vol. 45, pp. 43-57, 2014, doi: 10.1007/s10780-014-9219-1.

[11] R. Nelson and P. Dawson, "A Contribution to the History of Assessment: How a Conversation Simulator Redeems Socratic Method," Routledge J. Assess. Eval. High. Educ., vol. 39, no. 2, pp. 195-204, 2014, doi: $10.1080 / 02602938.2013 .798394$.

[12] R. L. Roth, "The Socratic Method Reloaded : a Rereading to Improve a Technologically Sound Education," Int. J. Learn. Teach. Educ. Res., vol. 15 , no. 6 , pp. 1-32, 2016.

[13] T. Tofade, J. Elsner, and S. T. Haines, "Best Practice Strategies for Effective Use of Questions as a Teaching Tool," Am. J. Pharm. Educ., vol. 77, no. 7, 2013.

[14] U. Kühnen et al., "Challenge Me ! Communicating in Multicultural Classrooms," Springer J. Soc. Psychol. Educ., vol. 15, pp. 5976, 2012, doi: 10.1007/s11218-011-9169-8.

[15] L. Elder and R. Paul, "Critical Thinking: The Art of Socratic Questioning, Part II," Proquest Prof. Educ. J. Dev. Educ., vol. 31, no. 2, pp. 3233, 2007.

[16] H. M. Altorf, "Dialogue and Discussion: Reflections on a Socratic Method," SAGE J. Arts Humanit. High. Educ., vol. 0, no. 0, pp. 116, 2016, doi: 10.1177/1474022216670607. 
[17] E. Babaii and S. Taghaddomi, "Speaking SelfAssessment : Mismatches between Learners , and Teachers ' Criteria," SAGE J. Lang. Test., pp. 1-27, 2015, doi:

$10.1177 / 0265532215590847$.

[18] L. R. Burns, P. L. Stephenson, and K. Bellamy, "The Socratic Method : Empirical Assessment of a Psychology Capstone Course," SAGE J. Psychol. Learn. Teach., vol. 15, no. 3, pp. 370 383, 2016, doi: 10.1177/1475725716671824.

[19] J. W. Creswell, Research Design: Qualitative, Quantitative and Mixed methods Approaches. USA: SAGE Publications Ltd, 2014.

[20] M. Copeland, Socratic Circles: Fostering Critical and Creative Thinking in Middle and High School. Portland, MN: Stenhouse, 2005.

[21] N. Burbules, Dialogue in teaching: Theory and practice. New York: Teachers College Press, 1993.

[22] S. M. Araghi and R. J. Amineh, "Review of Problems of Adults EFL Learners ' ( EFL ) Speaking," Int. J. Lang. Learn. Appl. Linguist. World, vol. 7, no. 2, pp. 419-431, 2014.

[23] B. Cussack and S. McCarter, Listening and Speaking Skills. Oxford: Macmillan Publishers, 2007.

[24] I. S. P. Nation and J. Newton, Teaching ESL/EFL Listening and Speaking. New York and London: Routledge Falmer, Taylor \& Francis Group, 2009.

[25] S. Thornbury, How to Teach Speaking. UK: Pearson, Longman, 2005.

[26] R. W. Paul, Critical Thinking: What every person needs to survive in a rapidly changing world, J. Willson. Santa Rosa, CA: Foundation for Critical Thinking, 1993.

[27] M. Mott, "The Use of the Socratic Method in an English Language Learning Classroom to Develop a Global Professional Skill," Appl. Linguist., vol. 13, no. 4, pp. 43-50, 2015.

[28] J. Pokorna, "Socratic Method and its use in English language teaching," Masaryk University, 2009.

[29] R. Paul, L. Elder, and T. Bartell, "The California teacher preparation for instruction in critical thinking: Research findings and policy recommendations," Sacramento, California, 1997.
[30] K. M. Kabilan, "Creative and critical thinking in language classroom," Internet TESL J., vol. 6, no. 6,2000 . 